\title{
Zinc and Cadmium Toxicity Using a Biotest with Artemia franciscana
}

\author{
J. NOVÁKOVÁ ${ }^{1}$, D. DAŇOVÁ ${ }^{1}$, K. STRIŠKOVÁ ${ }^{1}$, R. HROMADA², H. MIČKOVÁ ${ }^{3}$ \\ M. RABIŠKOVÁ ${ }^{4}$ \\ ${ }^{1}$ Department of Radiobiology, University of Veterinary Medicine Košice, Slovak Republic \\ ${ }^{2}$ Department of Environment, University of Veterinary Medicine Košice, Slovak Republic \\ ${ }^{3}$ Department of Medical Biology, Faculty of Medicine, University of Pavol Jozef Šafárik Košice, \\ Slovak Republic \\ ${ }^{4}$ Department of Pharmaceutics, Faculty of Pharmacy, University of Veterinary and \\ Pharmaceutical Sciences Brno, Czech Republic
}

Received May 21, 2007

Accepted October 2, 2007

\begin{abstract}
Nováková J., D. Daňová, K. Strišková, R. Hromada, H. Mičková, M. Rabišková: Zinc and Cadmium Toxicity Using a Biotest with Artemia franciscana. Acta Vet. Brno 2007, 76: 635-642.

Of the various toxic elements heavy metals, particularly cadmium, lead, mercury and zinc, occur frequently in the environment due to their relatively high industrial use. While the toxicity of individual substances is usually well known, information about their mutual interactions is relatively scarce. In animal experiments the prevailing trend is to substitute higher vertebrates with biotests of the $2^{\text {nd }}$ generation. Our experiment focused on observation of the effect of combinations of $\mathrm{ZnSO}_{4} \cdot 7 \mathrm{H}_{2} \mathrm{O}$ and $\mathrm{CdCl}_{2} \cdot 2 \mathrm{H}_{2} \mathrm{O}$ on lethality to Artemia franciscana. The aim of the study was to observe the synergistic or antagonistic effects of these two metals.

Depending on concentration, cadmium may increase or decrease the toxicity of zinc. At higher concentrations of $\mathrm{CdCl}_{2} .2 \mathrm{H}_{2} \mathrm{O}$ exceeding $100 \mathrm{mg} \cdot 1^{-1}$ one can observe obvious synergistic toxic effects of both the substances. Our observations allowed us to conclude that the use of optimum, relatively low concentrations of cadmium (up to $50 \mathrm{mg} \cdot \mathrm{l}^{-1} \mathrm{CdCl}_{2} \cdot 2 \mathrm{H}_{2} \mathrm{O}$ ) results in a significant decrease in lethality to Artemia franciscana caused by $\mathrm{ZnSO}_{4} \cdot 7 \mathrm{H}_{2} \mathrm{O}$ at concentrations of 50,100 a $250 \mathrm{mg} \cdot \cdot^{-1}$.

Artemia franciscana, crustacean, cadmium, lethality, nauplii, zinc
\end{abstract}

Modern civilization together with increased industrial activities brought gradual redistribution of a number of toxic elements from the terrestrial crust into the environment and thus increased the potential exposure of humans and animals. With increasing pollution also the interest arises in consequences of the action of xenobiotics, including hazardous chemical elements, on live organisms (Kovalkovičová et al. 2000; Eliášová et al. 2003; Beyer et al. 2005; Obi et al. 2006; Žáková et al. 2006). Of the various toxic elements heavy metals, particularly cadmium, lead, mercury and zinc occur frequently in the environment due to their relatively high industrial use. The presence of these elements in tissues reflects the contact of organisms with their environment (Pechová et al. 1998). They belong to cumulative poisons that are toxic at low doses. The metabolism and toxicity of these elements depend to a considerable degree on their interactions with essential elements that are necessary for the nutrition of live organisms, such as calcium, zinc, iron, selenium, copper, chromium and manganese.

From the viewpoint of water pollution observation it is suitable to focus on the examination of water plankton. This may include observation of direct pollution of aqueous environment, i.e. the effect of pollutants on plankton and its organisms, or observation of accumulation of pollutants in the food chain, as plankton constitutes its lower links.

Cadmium belongs to heavy metals widely distributed in the environment. It is present

Address for correspondence:

MVDr. Jaroslava Nováková

University of Veterinary Medicine in Košice

Department of Radiobiology

Komenského 73

Phone: +421903934543

04181 Košice, Slovak Republic

E-mail: novaks@internetkosice.sk

http://www.vfu.cz/acta-vet/actavet.htm 
in trace amounts in the oceans and in a wide range of plant and animal species. In nature, it is found together with zinc at a ratio of $1: 100$, or even $1: 1000$. It is obtained as a by-product of refining. Cadmium compounds are used in the electroplating of metals, alkaline batteries or in compounds with other metals. Relatively high quantities of cadmium are present in phosphate fertilisers (from some locations), which increase the concentration of cadmium in soil and plants. Cadmium is an element highly toxic to organisms living in the aqueous environment (Koréneková et al. 2002; Drastichová et al. 2004). This is only one of the reasons why the crustacean Artemia franciscana is a suitable subject of these studies. The current trend in toxicology is the reduction of experiments on higher vertebrates. One of the possibilities is the use of alternative biotest of the $2^{\text {nd }}$ generation performed on A. franciscana (Dvořák 1995; Dvořák and Beňová 2002). For conducting detailed observations the prolonged 10-day biotest is a more suitable alternative (Dvořák et al. 2005). With regard to the taxonomic revisions in nomenclature of the order Artemia, the majority of older studies referred to this species as Artemia salina.

Zinc is one of the elements that can decrease the toxicity of orally administered cadmium and its effect can be observed in competition with cadmium in certain transportation systems as well as at binding sites on metallothionein (McDowell 1992; Barata et al. 2002; Seebaugh and Wallace 2004).

Zinc and cadmium do not occur in the organism separately but they are bound to metallothionein - an intracellular, low-molecular protein rich in cysteine. Only after blocking all binding sites on this protein, the metals pass to the blood and tissues as free ions and cause intoxication. Under the action of medium and low concentrations of zinc and low concentrations of cadmium the metallothionein synthesis increases within several hours, which in turn increases the binding capacity of heavy metals (Barata et al. 2002; Trinchella et al. 2006).

However, if the time for metallothionein synthesis is insufficient due to parallel administration of zinc and cadmium, statistically significant changes in the influence of zinc on the prevention of cadmium toxicity can not be observed (Hua-Luo et al. 2002; Martinez et al. 1999).

The aim of the present study was to observe synergistic and antagonistic effects of cadmium and zinc in the form of water-soluble salts of zinc sulphate and cadmium chloride on lethality to Artemia franciscana.

\section{Materials and Methods}

The experiment was carried out employing a 10-day biotest (Dvořák et al. 2005). We used Artemia franciscana hatched in sea-water (Dvořák 1995). Ten freshly hatched nauplii were placed into polystyrene Petri dishes, 60 $\mathrm{mm}$ in diameter, and the total content of sea-water was $10 \mathrm{ml}$ including the sample. A. franciscana were provided glucose as an additional feed (Dvořák et al. 2005). During the experiment we used solutions of cadmium chloride $\left(\mathrm{CdCl}_{2} .2 \mathrm{H}_{2} \mathrm{O}\right)$ at concentrations of $5,10,15,25,50,100$ and $250 \mathrm{mg}$ and of zinc sulphate $\left(\mathrm{ZnSO}_{4} .7 \mathrm{H}_{2} \mathrm{O}\right)$ at concentrations of $50 \mathrm{mg}, 100 \mathrm{mg}$ and $250 \mathrm{mg}$. All solutions used in our experiments were prepared in sea-water. The study was conducted on 27 experimental groups and one control group (pure sea-water).

In every experiment we used $50 \mathrm{~A}$. franciscana divided into 5 individual groups (dishes), $10 \mathrm{~A}$. franciscana in each. Therefore 1,400 individual $A$. franciscana were used in the study. Petri dishes were placed into a thermostat set to the temperature of $20 \pm 1^{\circ} \mathrm{C}$. During the subsequent 10 days the live $A$. franciscana were counted once in $24 \mathrm{~h}$.

As we were interested in the synergistic or antagonistic effects of the selected chemical substances, we compared the results obtained in the experimental groups (marked in our case Zn 50, Zn 100 and $\mathrm{Zn} \mathrm{250)} \mathrm{and}$ evaluated them statistically. In order to eliminate the distant values we used the Dean-Dixon test. The significance of differences between individual A. franciscana groups was tested (Wayland and Hayes 1991).

\section{Results}

Fig. 1 and tables include the control group that was not exposed to any chemical substance added artificially to the aqueous environment because the lethality in this 
Table 1. Experimental A. franciscana were divided to 27 experimental groups as follows

\begin{tabular}{|c|c|c|}
\hline Identification of groups & $\begin{array}{c}\text { Concentration of } \\
\mathrm{CdCl}_{2} \cdot 2 \mathrm{H}_{2} \mathrm{O}\left(\mathrm{mg} \cdot \mathrm{l}^{-1}\right)\end{array}$ & $\begin{array}{c}\text { Concentration of } \\
\mathrm{ZnSO}_{4} \cdot 7 \mathrm{H}_{2} \mathrm{O}\left(\mathrm{mg} \cdot \mathrm{l}^{-1}\right)\end{array}$ \\
\hline $\mathrm{Cd} 5$ & 5 & 0 \\
\hline $\mathrm{Cd} 10$ & 10 & 0 \\
\hline $\mathrm{Cd} 25$ & 25 & 0 \\
\hline $\mathrm{Cd} 50$ & 50 & 0 \\
\hline Cd100 & 100 & 0 \\
\hline $\mathrm{Cd} 250$ & 250 & 0 \\
\hline $\mathrm{Zn50}$ & 0 & 50 \\
\hline Zn100 & 0 & 100 \\
\hline $\mathrm{Zn} 250$ & 0 & 250 \\
\hline Zn50Cd5 & 5 & 50 \\
\hline Zn50Cd10 & 10 & 50 \\
\hline Zn50Cd25 & 25 & 50 \\
\hline Zn50Cd50 & 50 & 50 \\
\hline Zn50Cd100 & 100 & 50 \\
\hline $\mathrm{Zn} 50 \mathrm{Cd} 250$ & 250 & 50 \\
\hline Zn100Cd5 & 5 & 100 \\
\hline $\mathrm{Zn} 100 \mathrm{Cd} 10$ & 10 & 100 \\
\hline $\mathrm{Zn} 100 \mathrm{Cd} 25$ & 25 & 100 \\
\hline $\mathrm{Zn} 100 \mathrm{Cd} 50$ & 50 & 100 \\
\hline Zn100Cd100 & 100 & 100 \\
\hline $\mathrm{Zn} 100 \mathrm{Cd} 250$ & 250 & 100 \\
\hline $\mathrm{Zn} 250 \mathrm{Cd} 5$ & 5 & 250 \\
\hline $\mathrm{Zn} 250 \mathrm{Cd} 10$ & 10 & 250 \\
\hline $\mathrm{Zn} 250 \mathrm{Cd} 25$ & 25 & 250 \\
\hline $\mathrm{Zn} 250 \mathrm{Cd} 50$ & 50 & 250 \\
\hline $\mathrm{Zn} 250 \mathrm{Cd} 100$ & 100 & 250 \\
\hline $\mathrm{Zn} 250 \mathrm{Cd} 250$ & 250 & 250 \\
\hline
\end{tabular}

group even after $240 \mathrm{~h}$ was lower than $20 \%$. This condition must be met in order to evaluate the test (Dvoŕák et al. 2005). All other results are presented in Tables 2 and 3 and in Fig. 1. For both separately acting zinc ( $\mathrm{Zn} \mathrm{50,} \mathrm{Zn} 100$ and $\mathrm{Zn}$ 250) and cadmium ( $\mathrm{Cd} 5$ to $\mathrm{Cd}$ 250) the relationship between lethality and concentration is obvious. These groups served as comparison groups for the studies of mutual interactions.

A significant increase in lethality compared to the first zinc exposure ( $\mathrm{Zn}$ 50) was observed on day 8 of observation with the combination $\mathrm{Zn} 50 \mathrm{Cd} 50$, on days 6 to 8 with the combination $\mathrm{Zn} 50 \mathrm{Cd} 100$ and on days 3 to 8 with the combination Zn50Cd250.

A significant decrease in lethality compared to the lowest zinc exposure group ( $\mathrm{Zn} 50)$ was recorded on days 9 and 10 with combination $\mathrm{Zn} 50 \mathrm{Cd} 5$ and on day 6 with combination Zn50Cd10.

A significant increase in lethality compared to the second zinc exposure group ( $\mathrm{Zn} 100)$ was observed on day 4 with combinations $\mathrm{Zn} 100 \mathrm{Cd} 25$ and $\mathrm{Zn} 100 \mathrm{Cd} 50$, on days 3 to 6 from the beginning of the experiment with the combination $\mathrm{Zn} 100 \mathrm{Cd} 100$ and on days 2 to 8 with the combination $\mathrm{Zn} 100 \mathrm{Cd} 250$.

A significant decrease in lethality compared to the second zinc exposure group (Zn 100) was detected on days 5 to 10 with combinations $\mathrm{Zn} 100 \mathrm{Cd} 5$ and $\mathrm{Zn} 100 \mathrm{Cd} 10$ and on days 7 to 10 with combinations $\mathrm{Zn} 100 \mathrm{Cd} 25$ and $\mathrm{Zn} 100 \mathrm{Cd} 50$.

A significant increase in lethality compared to the third zinc exposure group ( $\mathrm{Zn} 250$ ) was observed on days 3 to 6 with combination Zn250Cd100 and as early as on days 2 to 7 with combination $\mathrm{Zn} 250 \mathrm{Cd} 250$.

A significant decrease in lethality compared to the third zinc exposure group ( $\mathrm{Zn} 250$ ) was recorded on days 6 to 10 with the combination $\mathrm{Zn} 250 \mathrm{Cd} 5$, on days 7 to 9 with the combination $\mathrm{Zn} 250 \mathrm{Cd} 10,6$ to 9 with the combination $\mathrm{Zn} 250 \mathrm{Cd} 25$ and 7 to 8 with the combination Zn250Cd50 (Tables 2 and 3).

Other differences were statistically non-significant.

The effect of interactions of low cadmium concentrations ( $\mathrm{Cd} \mathrm{5,} \mathrm{Cd} 10$ and $\mathrm{Cd} 25)$ is illustrated in Fig. 1. This graph indicates that the toxicity of individual concentrations of zinc is decreased by low concentrations of cadmium used in optimum concentration combinations. 
Table 2. Lethality to Artemia franciscana (\%) resulting from single action either of cadmium chloride $\left(\mathrm{CdCl}_{2} \cdot 2 \mathrm{H}_{2} \mathrm{O}\right)$ or zinc sulphate $\left(\mathrm{ZnSO}_{4} \cdot 7 \mathrm{H}_{2} \mathrm{O}\right)$ in dependence on the time of action

\begin{tabular}{|c|c|c|c|c|c|c|c|c|c|c|c|}
\hline Time & (h) & 24 & 48 & 72 & 96 & 120 & 144 & 168 & 192 & 216 & 240 \\
\hline \multirow{3}{*}{ Control } & $\mathrm{x}$ & 0 & 0 & 0 & 0 & 0 & 0 & 6 & 6 & 6 & 8 \\
\hline & $\mathrm{n}$ & 5 & 5 & 5 & 5 & 5 & 5 & 5 & 5 & 5 & 5 \\
\hline & $\mathrm{SD}$ & 0 & 0 & 0 & 0 & 0 & 0 & 4.3 & 4.3 & 4.3 & 4.3 \\
\hline \multirow{3}{*}{$\mathrm{Cd} 5$} & $\mathrm{x}$ & 0 & 0 & 0 & 0 & 0 & 2 & 18 & 18 & 20 & 24 \\
\hline & $\mathrm{n}$ & 5 & 5 & 5 & 5 & 5 & 5 & 5 & 5 & 5 & 5 \\
\hline & $\mathrm{SD}$ & 0 & 0 & 0 & 0 & 0 & 4.3 & 4.3 & 4.3 & 0 & 8.6 \\
\hline \multirow{3}{*}{$\mathrm{Cd} 10$} & $\mathrm{x}$ & 0 & 0 & 0 & 0 & 4 & 10 & 16 & 16 & 24 & 56 \\
\hline & $\mathrm{n}$ & 5 & 5 & 5 & 5 & 5 & 5 & 5 & 5 & 5 & 5 \\
\hline & SD & 0 & 0 & 0 & 0 & 4.3 & 0 & 4.3 & 4.3 & 4.3 & 8.6 \\
\hline \multirow{3}{*}{$\mathrm{Cd} 25$} & $\mathrm{x}$ & 0 & 0 & 0 & 0 & 0 & 2 & 28 & 36 & 50 & 80 \\
\hline & $\mathrm{n}$ & 5 & 5 & 5 & 5 & 5 & 5 & 5 & 5 & 5 & 5 \\
\hline & SD & 0 & 0 & 0 & 0 & 0 & 4.3 & 4.3 & 8.6 & 4.3 & 8.6 \\
\hline \multirow{3}{*}{$\mathrm{Cd} 50$} & $\mathrm{x}$ & 0 & 2 & 4 & 6 & 14 & 50 & 58 & 68 & 76 & 86 \\
\hline & $\mathrm{n}$ & 5 & 5 & 5 & 5 & 5 & 5 & 5 & 5 & 5 & 5 \\
\hline & SD & 0 & 4.3 & 4.3 & 4.3 & 4.3 & 8.6 & 4.3 & 12.9 & 8.6 & 12.9 \\
\hline \multirow{3}{*}{$\mathrm{Cd} 100$} & $x$ & 0 & 2 & 18 & 24 & 32 & 80 & 94 & 98 & 100 & 100 \\
\hline & $\mathrm{n}$ & 5 & 5 & 5 & 5 & 5 & 5 & 5 & 5 & 5 & 5 \\
\hline & $\mathrm{SD}$ & 0 & 4.3 & 4.3 & 8.6 & 8.6 & 17.2 & 12.9 & 4.3 & 0 & 0 \\
\hline \multirow{3}{*}{$\mathrm{Cd} 250$} & $\mathrm{x}$ & 0 & 6 & 22 & 62 & 78 & 96 & 98 & 100 & 100 & 100 \\
\hline & $\mathrm{n}$ & 5 & 5 & 5 & 5 & 5 & 5 & 5 & 5 & 5 & 5 \\
\hline & $\mathrm{SD}$ & 0 & 4.3 & 4.3 & 12.9 & 12.9 & 4.3 & 4.3 & 0 & 0 & 0 \\
\hline \multirow{3}{*}{$\mathrm{Zn} 50$} & $\mathrm{x}$ & $0+$ & $0+$ & $0+$ & $0+$ & $16+$ & $28+$ & $46+$ & $50+$ & $96+$ & $100+$ \\
\hline & $\mathrm{n}$ & 5 & 5 & 5 & 5 & 5 & 5 & 5 & 5 & 5 & 5 \\
\hline & $\mathrm{SD}$ & 0 & 0 & 0 & 0 & 4.3 & 8.6 & 8.6 & 4.3 & 4.3 & 0 \\
\hline \multirow{3}{*}{ Zn50Cd5 } & $\mathrm{x}$ & 0 & 0 & 0 & 0 & 10 & 18 & 36 & 46 & $78 *$ & $86^{*}$ \\
\hline & $\mathrm{n}$ & 5 & 5 & 5 & 5 & 5 & 5 & 5 & 5 & 5 & 5 \\
\hline & $\mathrm{SD}$ & 0 & 0 & 0 & 0 & 4.3 & 8.6 & 8.6 & 8.6 & 4.3 & 8.6 \\
\hline \multirow{3}{*}{$\mathrm{Zn} 50 \mathrm{Cd} 10$} & $\mathrm{x}$ & 0 & 0 & 0 & 0 & 6 & $12 *$ & 44 & 64 & 84 & 96 \\
\hline & $\mathrm{n}$ & 5 & 5 & 5 & 5 & 5 & 5 & 5 & 5 & 5 & 5 \\
\hline & SD & 0 & 0 & 0 & 0 & 4.3 & 4.3 & 8.6 & 12.9 & 12.9 & 4.3 \\
\hline \multirow{3}{*}{$\mathrm{Zn} 50 \mathrm{Cd} 25$} & $\mathrm{x}$ & 0 & 4 & 4 & 6 & 10 & 18 & 36 & 50 & 88 & 98 \\
\hline & $\mathrm{n}$ & 5 & 5 & 5 & 5 & 5 & 5 & 5 & 5 & 5 & 5 \\
\hline & $\mathrm{SD}$ & 0 & 4.3 & 4.3 & 4.3 & 0 & 4.3 & 8.6 & 4.3 & 12.9 & 4.3 \\
\hline
\end{tabular}

$\left(+^{*}\right)$ differences between the values marked with the same symbol were significant $(\alpha=0.05)$

$\mathrm{n}$ number of Petri dishes, each containing 10 nauplii

$\mathrm{X}$ arithmetical mean

SD standard deviation

\section{Discussion}

Cadmium is an element highly toxic to live organisms (Koréneková et al. 2002). Its toxicity was described also for organisms living in the aqueous environment (Drastichová et al. 2004). For this reason it appeared advantageous to use the crustacean $A$. franciscana in our experiments (Dvořák 1999). The alternative 10-day biotest was used for the first time to examine the mutual interactions of toxic elements. Its main advantage is the limited influence of biological variability, i.e. random results. Our study was conducted on a large number of experimental crustaceans (28 groups, 50 in each, i.e. 1,400 A. franciscana). An experiment of similar extent can hardly be conducted on higher vertebrates or it would require extraordinary expenses. 
Table 3. Lethality to Artemia franciscana (\%) resulting from single action either of cadmium chloride $\left(\mathrm{CdCl}_{2} \cdot 2 \mathrm{H}_{2} \mathrm{O}\right)$ or zinc sulphate $\left(\mathrm{ZnSO}_{4} \cdot 7 \mathrm{H}_{2} \mathrm{O}\right)$ in dependence on the time of action

\begin{tabular}{|c|c|c|c|c|c|c|c|c|c|c|c|}
\hline Time & (h) & 24 & 48 & 72 & 96 & 120 & 144 & 168 & 192 & 216 & 240 \\
\hline \multirow{3}{*}{ Zn50Cd50 } & $\mathrm{x}$ & 0 & 0 & 6 & 10 & 22 & 32 & 58 & 76 & 90 & 94 \\
\hline & $\mathrm{n}$ & 5 & 5 & 5 & 5 & 5 & 5 & 5 & 5 & 5 & 5 \\
\hline & SD & 0 & 0 & 4.3 & 4.3 & 4.3 & 8.6 & 4.3 & 17.2 & 8.6 & 4.3 \\
\hline \multirow{3}{*}{ Zn50Cd100 } & $x$ & 0 & 0 & 2 & 4 & 18 & $50^{*}$ & $70^{*}$ & $88^{*}$ & 100 & 100 \\
\hline & $\mathrm{n}$ & 5 & 5 & 5 & 5 & 5 & 5 & 5 & 5 & 5 & 5 \\
\hline & SD & 0 & 0 & 4.3 & 4.3 & 4.3 & 8.6 & 17.2 & 12.9 & 0 & 0 \\
\hline \multirow{3}{*}{$\mathrm{Zn} 50 \mathrm{Cd} 250$} & $\mathrm{x}$ & 0 & 6 & $42^{*}$ & $54^{*}$ & $98^{*}$ & $100^{*}$ & $100^{*}$ & $100^{*}$ & 100 & 100 \\
\hline & $\mathrm{n}$ & 5 & 5 & 5 & 5 & 5 & 5 & 5 & 5 & 5 & 5 \\
\hline & SD & 0 & 4.3 & 12.9 & 8.6 & 4.3 & 0 & 0 & 0 & 0 & 0 \\
\hline \multirow{3}{*}{$\mathrm{Zn} 100$} & $\mathrm{x}$ & $0+$ & $0+$ & $0+$ & $0+$ & $22+$ & $40+$ & $70+$ & $78+$ & $88+$ & $100+$ \\
\hline & $\mathrm{n}$ & 5 & 5 & 5 & 5 & 5 & 5 & 5 & 5 & 5 & 5 \\
\hline & $\mathrm{SD}$ & 0 & 0 & 0 & 0 & 8.6 & 8.6 & 17.2 & 8.6 & 8.6 & 0 \\
\hline \multirow{3}{*}{ Zn100Cd5 } & $\mathrm{x}$ & 0 & 0 & 0 & 0 & $0^{*}$ & $10^{*}$ & $10^{*}$ & $18^{*}$ & $42^{*}$ & $54 *$ \\
\hline & $\mathrm{n}$ & 5 & 5 & 5 & 5 & 5 & 5 & 5 & 5 & 5 & 5 \\
\hline & SD & 0 & 0 & 0 & 0 & 0 & 4.3 & 4.3 & 4.3 & 8.6 & 17.2 \\
\hline \multirow{3}{*}{ Zn100Cd10 } & $\mathrm{x}$ & 0 & 0 & 2 & 2 & $6^{*}$ & $12^{*}$ & $16^{*}$ & $22^{*}$ & $56^{*}$ & $74^{*}$ \\
\hline & $\mathrm{n}$ & 5 & 5 & 5 & 5 & 5 & 5 & 5 & 5 & 5 & 5 \\
\hline & SD & 0 & 0 & 4.3 & 4.3 & 4.3 & 4.3 & 8.6 & 8.6 & 17.2 & 17.2 \\
\hline \multirow{3}{*}{$\mathrm{Zn} 100 \mathrm{Cd} 25$} & $x$ & 0 & 4 & 10 & $14^{*}$ & 14 & 26 & $26^{*}$ & $38^{*}$ & $66^{*}$ & $78^{*}$ \\
\hline & $\mathrm{n}$ & 5 & 5 & 5 & 5 & 5 & 5 & 5 & 5 & 5 & 5 \\
\hline & SD & 0 & 4.3 & 0 & 4.3 & 8.6 & 8.6 & 8.6 & 8.6 & 17.2 & 17.2 \\
\hline \multirow{3}{*}{ Zn100Cd50 } & $\mathrm{x}$ & 0 & 0 & 10 & $14^{*}$ & 14 & 24 & $28^{*}$ & $36^{*}$ & $70^{*}$ & $86^{*}$ \\
\hline & $\mathrm{n}$ & 5 & 5 & 5 & 5 & 5 & 5 & 5 & 5 & 5 & 5 \\
\hline & SD & 0 & 0 & 8.6 & 4.3 & 4.3 & 4.3 & 8.6 & 12.9 & 8.6 & 8.6 \\
\hline \multirow{3}{*}{$\mathrm{Zn} 100 \mathrm{Cd} 100$} & $\mathrm{x}$ & 0 & 2 & $26^{*}$ & $34^{*}$ & $40^{*}$ & $68^{*}$ & 76 & 80 & 92 & 96 \\
\hline & $\mathrm{n}$ & 5 & 5 & 5 & 5 & 5 & 5 & 5 & 5 & 5 & 5 \\
\hline & SD & 0 & 4.3 & 12.9 & 8.6 & 8.6 & 12.9 & 12.9 & 17.2 & 8.6 & 8.6 \\
\hline \multirow{3}{*}{$\mathrm{Zn} 100 \mathrm{Cd} 250$} & $\mathrm{x}$ & 0 & $52 *$ & $96 *$ & $96^{*}$ & $98^{*}$ & $100^{*}$ & $100^{*}$ & $100^{*}$ & 100 & 100 \\
\hline & $\mathrm{n}$ & 5 & 5 & 5 & 5 & 5 & 5 & 5 & 5 & 5 & 5 \\
\hline & SD & 0 & 12.9 & 4.3 & 4.3 & 4.3 & 0 & 0 & 0 & 0 & 0 \\
\hline \multirow{3}{*}{$\mathrm{Zn} 250$} & $\mathrm{X}$ & $0+$ & $0+$ & $14+$ & $14+$ & $24+$ & $42+$ & $84+$ & $100+$ & $100+$ & $100+$ \\
\hline & $n$ & 5 & 5 & 5 & 5 & 5 & 5 & 5 & 5 & 5 & 5 \\
\hline & SD & 0 & 0 & 4.3 & 4.3 & 4.3 & 8.6 & 12.9 & 0 & 0 & 0 \\
\hline \multirow{3}{*}{$\mathrm{Zn} 250 \mathrm{Cd} 5$} & $\mathrm{x}$ & 0 & 2 & 8 & 10 & 16 & $18^{*}$ & $20^{*}$ & $42^{*}$ & $74^{*}$ & $78^{*}$ \\
\hline & $\mathrm{n}$ & 5 & 5 & 5 & 5 & 5 & 5 & 5 & 5 & 5 & 5 \\
\hline & SD & 0 & 4.3 & 4.3 & 0 & 4.3 & 4.3 & 4.3 & 8.6 & 17.2 & 17.2 \\
\hline \multirow{3}{*}{ Zn250Cd10 } & $\mathrm{x}$ & 0 & 2 & 22 & 24 & 26 & 32 & $40^{*}$ & $58^{*}$ & $78^{*}$ & $88^{*}$ \\
\hline & $n$ & 5 & 5 & 5 & 5 & 5 & 5 & 5 & 5 & 5 & 5 \\
\hline & SD & 0 & 4.3 & 8.6 & 4.3 & 4.3 & 8.6 & 4.3 & 17.2 & 17.2 & 17.2 \\
\hline \multirow{3}{*}{$\mathrm{Zn} 250 \mathrm{Cd} 25$} & $\mathrm{x}$ & 0 & 4 & 6 & 12 & 18 & $20 *$ & $36^{*}$ & $52^{*}$ & $82 *$ & 90 \\
\hline & $\mathrm{n}$ & 5 & 5 & 5 & 5 & 5 & 5 & 5 & 5 & 5 & 5 \\
\hline & SD & 0 & 4.3 & 4.3 & 4.3 & 4.3 & 0 & 8.6 & 17.2 & 8.6 & 8.6 \\
\hline \multirow{3}{*}{$\mathrm{Zn} 250 \mathrm{Cd} 50$} & $\mathrm{x}$ & 0 & 0 & 22 & 26 & 32 & 44 & $48^{*}$ & $82^{*}$ & 94 & 96 \\
\hline & $\mathrm{n}$ & 5 & 5 & 5 & 5 & 5 & 5 & 5 & 5 & 5 & 5 \\
\hline & SD & 0 & 0 & 8.6 & 8.6 & 12.9 & 8.6 & 17.2 & 8.6 & 4.3 & 4.3 \\
\hline \multirow{3}{*}{ Zn250Cd100 } & $\mathrm{x}$ & 0 & 6 & $36^{*}$ & $56^{*}$ & $68 *$ & $76^{*}$ & 86 & 98 & 98 & 100 \\
\hline & $n$ & 5 & 5 & 5 & 5 & 5 & 5 & 5 & 5 & 5 & 5 \\
\hline & SD & 0 & 8.6 & 4.3 & 8.6 & 12.9 & 17.2 & 12.9 & 4.3 & 4.3 & 0 \\
\hline \multirow{3}{*}{$\mathrm{Zn} 250 \mathrm{Cd} 250$} & $x$ & 0 & $58^{*}$ & $96^{*}$ & $100^{*}$ & $100^{*}$ & $100^{*}$ & $100^{*}$ & 100 & 100 & 100 \\
\hline & $\mathrm{n}$ & 5 & 5 & 5 & 5 & 5 & 5 & 5 & 5 & 5 & 5 \\
\hline & SD & 0 & 8.6 & 4.3 & 0 & 0 & 0 & 0 & 0 & 0 & 0 \\
\hline
\end{tabular}

$(+*)$ differences between the values marked with the same symbol were significant $(\alpha=0.05)$ number of Petri dishes, each containing 10 nauplii

$\mathrm{X}$ arithmetical mean

SD standard deviation 


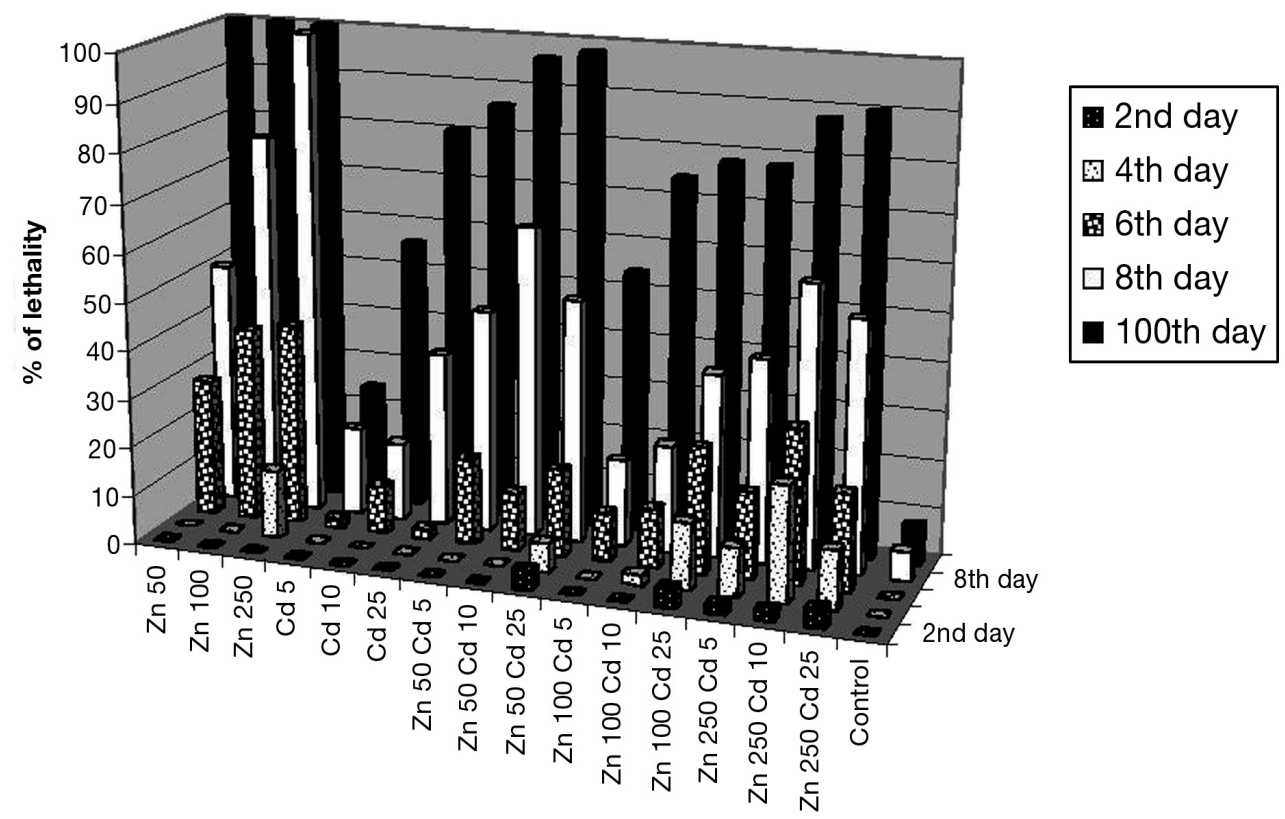

Fig. 1. Lethality to Artemia franciscana (\%) resulting from combinations of cadmium chloride $\left(\mathrm{CdCl}_{2} .2 \mathrm{H}_{2} \mathrm{O}\right)$ and zinc sulphate $\left(\mathrm{ZnSO}_{4} \cdot 7 \mathrm{H}_{2} \mathrm{O}\right)$

It has been recognised that zinc is one of the elements that can decrease the toxicity of orally administered cadmium. Its effect has been observed in competition with cadmium in certain transport systems or for binding sites on metallothionein (McDowell 1992; Barata et al. 2002; Seebaugh and Wallace 2004). Zinc has a favourable effect on liver cells, protecting them against damage and helping to preserve membrane integrity through direct action on free radicals. When administered before or together with cadmium, it can protect kidneys against the nephrotoxic effect of cadmium without decreasing its level in this organ.

Zinc and cadmium do not occur alone in the organism but they are bound to metallothionein - an intracellular, low-molecular protein rich in cysteine. Only after all binding sites on this protein become occupied, the metals pass to blood and tissues as free ions and cause intoxication. Under the action of medium and low concentrations of zinc and low concentrations of cadmium the metallothionein synthesis increases within several hours which results in the increase of binding capacity for heavy metals (Barata et al. 2002; Trinchella et al. 2006). However, if the time for metallothionein synthesis is insufficient due to parallel administration of zinc and cadmium, one may observe no significant preventive effect of the addition of zinc on toxicity of cadmium (Hua et al. 2002; Martinez et al. 1999).

Studies of many authors indicated that the relationship between cadmium and zinc is important for the toxicology of cadmium (Dvořák 1999). The protective role of higher uptake of zinc during cadmium intoxication and higher accumulation and toxicity of cadmium during zinc deficiency suggest that the metabolism and effect of cadmium on the organism may be modified by regulation of the zinc uptake.

Additional multiple interactions can also play an important role. The study by Dvořák and Šcman (1996) reported interactions between cadmium chloride, potassium dichromate ${ }^{90} \mathrm{Sr}$ radionuclide and polychlorinated biphenyls. The paper mentioned predominantly only synergistic, toxicity-increasing effects. 
Contrary to the studies mentioned above, our experiments indicate that mutual combinations of individual concentrations of both elements are of decisive importance, i.e. suitably low concentrations of cadmium can also decrease toxicity of zinc which is an observation that has not been reported before. Toxicological hormesis can also be important with regard to the final effect (Beňová et al. 2007).

In conclusion, relatively high concentrations of zinc and cadmium resulted in a synergistic effect of these two metals. However, at suitable combinations of zinc and cadmium concentrations and elapse of sufficient time after the onset of action of these substances, a significant decrease in their lethality to A. franciscana was observed.

\section{Vplyv interakcií rôznych koncentrácií zinku a kadmia na letalitu Artemia franciscana}

Medzi rôznymi toxickými prvkami sa t'ažké kovy, najmä kadmium, olovo, ortut' a zinok, obvykle vyskytujú v životnom prostredí v dôsledku ich pomerne vysokého priemyselného použitia. Zatial' čo toxicita jednotlivých látok je známa, ich vzájomné interakcie sú známe pomerne málo. $V$ experimentoch sa s maximálnou možnou mierou nahrádzajú vyššie stavovce biotestami II. generácie. V našom experimente sme sledovali účinky kombinácií $\mathrm{ZnSO}_{4} \cdot 7 \mathrm{H}_{2} \mathrm{O}$ a $\mathrm{CdCl}_{2} \cdot 2 \mathrm{H}_{2} \mathrm{O}$ na letalitu Artemia franciscana. Ciel'om pokusu bolo sledovanie synergických alebo antagonistických účinkov týchto dvoch kovov.

V závislosti na koncentrácií, môže kadmium zvyšovat' i znižovat’ toxicitu zinku. U vyšších koncentrácií $\mathrm{CdCl}_{2} \cdot 2 \mathrm{H}_{2} \mathrm{O}$ nad $100 \mathrm{mg} \cdot \mathrm{l}^{-1}$ je viditel'ný synergický toxický účinok oboch látok. Z pozorovania však môžeme usúdit', že pri použití optimálnych, relatívne nízkych koncentrácií kadmia (do $50 \mathrm{mg} \cdot l^{-1} \mathrm{CdCl}_{2} \cdot 2 \mathrm{H}_{2} \mathrm{O}$ ) dochádza k výraznému zníženiu letality Artemia franciscana spôsobeného $\mathrm{ZnSO}_{4} \cdot 7 \mathrm{H}_{2} \mathrm{O}$ v koncentráciách 50,100 a $250 \mathrm{mg} \cdot{ }^{-1}$.

\section{Acknowledgement}

The study was supported by the project VEGA 1/2358/05 and VEGA 1/2378/05.

\section{References}

BARATA C, MARKICH SJ, BAIRD DJ, TAYLOR G, SOARES AMVM 2002: Genetic variability in sublethal tolerance to mixtures of cadmium and zinc in clones of Daphnia magna Straus. Aquat Toxicol 60: 85-99

BEŇOVÁ K, DVOŘÁK P, FALIS M, SKLENÁŘ Z 2007: Interaction of low doses of ionizing radiation, potassium dichromate and cadmium chloride in Artemia franciscana biotest. Acta Vet Brno 76: 35-40

BEYER WN, DALGARN J, DUDDING S, FRENCH JB, MATEO R, MIESNER J, SILEO L, SPANN J 2005 : Zinc and lead poisoning in wild birds in the Tri-State Mining District (Oklahoma, Kansas, and Missouri). Arch Environ Contam Toxicol 48: 108-117

DRASTICHOVÁ J, SVOBODOVÁ Z, LUSKOVÁ V, MÁCHOVÁ J 2004: Effect of cadmium on haematological indices of common carp (Cyprinus carpio L.). Bull Environ Contam Toxicol 72: 725-732

DVOŘÁK P 1995. A modified test for monitoring of interactions of hazard substances using A. salina. (In Czech). In: Sborník Toxicita a biodegradabilita odpadů a látek významných ve vodním prostředí. Výzkumný ústav rybářský a hydrobiologický a Aqachemie, Milenovice, pp. 25-29

DVOŘAK P, ŠUCMAN E 1996: Interactions of low activities of ${ }^{89} \mathrm{Sr}$ and low concentrations of heavy Metals and PCB in a Biological Experiment. Mengen und Spurenelemente. 1.Auflage. Verlag Harald Schubert, Leipzig \& Friedrich-Schiller-Universität Jena, pp. 576-583 (ISBN 3-929526-37-9)

DVOŘÁK P 1999: Observation of interactions of low exposure to ionising radiation and xenobiotics by means of biotest with Artemia salina (In Czech). (Habilitation thesis). VFU Brno, 194 p.

DVOŘÁK P, BEŇOVÁ K 2002: The investigation of interactions of low doses of ionizing radiation and risk factors by means of Artemia salina biotest. Folia Vet 46: 195-197

DVOŘÁK P, BEŇOVÁ K 2002: Observation of interactions of low doses of ionising radiation and risk elements by means of biotest with Artemia salina (In Slovak). In: Ecology and Veterinary Medicine V, UVL Košice, 53 p. (ISBN 80-88985-72-2).

DVORÁK P, ŠUCMAN E, BEŇOVÁ K 2005: The development of a ten-day biotest using Artemia salina nauplii. Biologia 60: 593-597

ELIÁŠOVÁ V, KOŽURKOVÁ M., KROPÁČOVÁ K 2003: The effect of cadmium and irradiation on histological and histone changes in rat. Folia Vet 47: 142-144

HUA L, BAY L, WEI DP, CHEN SB 2002: Effects of interaction by organic manure-Cd-Zn on Cd, Zn formation in soil and wheat growth. China Envir Science 22: 346-350 
KORÉNEKOVÁ B, SKALICKÁ M, NAĎ P 2002: Cadmium exposure of cattle after long-term emission from polluted area. Trace Elem Electrolytes 19: 97-99

KOVALKOVIČOVÁ N, KAČMÁR P, ŠUTIAKOVÁ I, ŠULÍK E, MIKULA I, PISTL J, MLYNARČÍKOVÁ H, LEGÁTH J 2000: Assessment of the ability of endosulfan to induce micronuclei in vitro in cultured sheep lymphocytes. J Trace Microprobe Techniq 18: 221-226

MARTINEZ M, DEL RAMO J, TORREBLANCA A, DIAZ-MAYANS J 1999: Effect of cadmium exposure on zinc levels in the brine shrimp Artemia parthenogenetica. Aquaculture 172: 315-325

McDOWELL LR 1992: Minerals in Animal and Human Nutrition. Academic Press, New York, pp. 359-361

OBI E, AKUNYILI DN., EKPO B, ORISAKWE OE 2006: Heavy metal hazards of Nigerian herbal remedies. Sci Total Environ 369: 35-41

PECHOVA A, ILLEK J, PAVLATA L, SINDELAR M, HORKY D 1998: Effects of chronic exposure to cadmium on state of health and accumulation in tissues of calves. Acta Vet Brno 67: 167-174

SEEBAUGH DR, WALLACE WG 2004: Importance of metal-binding proteins in the partitioning of $\mathrm{Cd}$ and $\mathrm{Zn}$ as trophically available metal (TAM) in the brine shrimp Artemia franciscana. Mar Ecol-Prog Ser 272: 215-230

TRINCHELLA F, RIGGIO M, FILOSA S, VOLPE MG., PARISI E, SCUDIERO R 2006: Cadmium distribution and metallothionein expression in lizard tissues following acute and chronic cadmium intoxication. Comp Biochem Physiol PT C 144: 272-278

WAYLAND J, HAYES JR 1991: Dosage and other factors influencing toxicity. Pesticide toxicology, Volume 1. General principles, Academic Press, pp. 39-97

ŽÁKOVÁ Z, KOČKOVÁ E, DVOŘÁK P, MLEJNEK P 2006: Bioakumulace těžkých kovů a radionuklidů ve sladkovodních houbách a sedimentech v nádrži Mohelno, ovlivněné provozem Jaderné elektrárny Dukovany. (Bioaccumulation of heavy metals and radionuclides in freshwater sponges and sediments in the Mohelno reservoir influenced by operation of the Dukovany nuclear power plant.) In Czech. Acta Rer Natur 2: 85-97 